\title{
Clonal Variations and Virus Regulation by Aphids in Transmission of a French PAV-Type Isolate of Barley Yellow Dwarf Virus
}

\author{
J.-Q. Guo, Unité de Zoologie; H. Lapierre, Unité de Pathologie Végétale; and J.-P. Moreau, Unité de Zoologie, \\ INRA, F - 78026 Versailles cedex, France
}

\begin{abstract}
Guo, J.-Q., Lapierre, H., and Moreau J.-P. 1997. Clonal variations and virus regulation by aphids in transmission of a French PAV-type isolate of barley yellow dwarf virus. Plant Dis. 81:570-575.

Twenty-one aphid clones of Rhopalosiphum padi and 21 clones of Sitobion avenae were evaluated for vector efficiency in transmitting a French PAV-type isolate (PAV-RG) of barley yellow dwarf virus (BYDV). All aphid clones transmitted the isolate, but vector efficiency was variable. The most efficient $R$. padi clone transmitted PAV-RG about twice as often as the least efficient one, Rp-CH (93 versus 38\%). The most efficient S. avenae clone, however, transmitted PAV-RG eight times more often than the least efficient one, Sa-R5 (76 versus 8\%). All aphid clones acquired virus as determined by triple antibody sandwich-enzyme-linked immunosorbent assay (TAS-ELISA), but the amount of virus acquired differed among the clones. After a 5-day inoculation access period on healthy plants, virus titer in some aphid clones was not detectable by TAS-ELISA in samples of 10 aphids, but immunocapture-polymerase chain reaction (ICPCR) could detect the virus in the extract of single aphids of all the clones. In most cases, a rapid reduction of PAV-RG titer in the aphids was associated with lower transmission efficiency. In a serial transmission test of 11 days, clonal variations in vector efficiency were consistently observed. After a 5-day transfer, vector efficiency of the six clones tested declined. Vector efficiency was significantly correlated with the level of virus titer in the aphids. Following the serial transfer, decline of virus titer in feeding aphids was triphasic, with an initial decrease occurring rapidly after the first transfer, then decreasing slowly. A second rapid reduction in virus titer often occurred after 7 days of transfer. In the serial transmission test, all three $R$. padi clones tested transmitted and retained virus until the last transfer at 11 days. The Sa-Chat 1 and $\mathrm{Sa}-\mathrm{V}$ clones of $S$. avenae successively transmitted and retained PAV-RG for 11 and 9 days, respectively. The Sa-R5 clone transmitted PAV-RG until the 9-day transfer, but retained the virus for 11 days. Thus, the clonal variations in vector efficiency were not ascribed to poor ability to acquire the virus, but were associated with a possible transmission barrier of virions, as well as a more rapid reduction of virus titer in aphids.
\end{abstract}

Barley yellow dwarf luteovirus (BYDV) comprises several serologically distinct viruses that infect both cultivated and wild plants in the family Poaceae. They are among the most widespread and economically important viruses affecting small grain crops throughout the world $(4,31)$. These viruses are obligately transmitted by aphids in a persistent, circulative manner. Because most of them have a high degree of vector specificity and are efficiently transmitted by one or two specific aphid species, they were initially differentiated on the basis of their most efficient vector (20). Among these luteoviruses, BYD-PAV can be efficiently transmitted by a few cereal aphid species, such as Rhopalosiphum padi L. and Sitobion avenae Fabr., and of-

Corresponding author: J.-Q. Guo. Present address: Institute of Plant Protection, Chinese Academy of Agricultural Sciences, Beijing 100094, P. R. China.

Accepted for publication 11 November 1996.

Publication no. D-1997-0401-04R

(C) 1997 The American Phytopathological Society ten occurs more frequently than the other luteoviruses in cereal crops in France. The vector specificity of these luteoviruses has been demonstrated to be the result of interactions between the structural proteins of virions and the membrane system of aphids $(8,9,14,16,30)$. The hypothesis of receptormediated endocytosis in regulating luteovirus recognition and transport in aphids was supported by several lines of evidence including the selective roles of hindgut membrane (8) and salivary gland basal lamina $(9,16)$. The selective recognition of luteoviruses by aphids is determined by genetics of both virus and aphid species. A better understanding of variations in vector efficiency within an aphid species is critical to the genetic analysis of transmission mechanisms.

Few studies have described clonal variations within an aphid species in ability to transmit BYDV (10,12,20,21). A clone comes from an aphid individual with genetic traits identical to the parent and should show no transmission variability from the parent. Variation in virus transmission efficiency can also result from a variety of factors, such as virus titer in the source plant, temperature, or developmental stage of aphid $(5,11,12,18)$. The variation that results from effects of the above factors may interfere with assessment of clonal variation in vector efficiency. Therefore, in controlled conditions, transmission tests combined with a study of virus regulation in aphids, using highly sensitive and specific methods to detect viruses in aphids, are essential to understand the clonal variation. Conventional detection by enzyme-linked immunosorbent assay (ELISA) is not sensitive enough to determine the duration of virus retention in aphids, particularly in the case of the viruses occurring in extremely low concentration $(1,22,26,27)$. While polymerase chain reaction (PCR) has been used to amplify plant viruses in single vectors $(7,15$, 23,29), the immunocapture (IC)-PCR method (13) is considered to be more sensitive $(24,32)$. To study the virus-aphid interaction, we have successfully adapted an IC-PCR method to detect BYDV in aphids. In this paper, we describe an application of IC-PCR and triple antibody sandwich (TAS)-ELISA methods to assess clonal variation within aphid species in transmission of BYD-PAV.

\section{MATERIALS AND METHODS}

Virus isolate and aphid clones. A French isolate of BYDV, PAV-RG (3), efficiently transmitted by $R$. padi and $S$. avenae, was maintained in barley (Hordeum vulgare L.). This isolate is a PAV serotype and causes severe stunting in barley cv. Plaisant seedlings (3). Virus source plants were regularly renewed by serial transmission to new barley seedlings at 4-week intervals, using viruliferous aphids of $R$. padi, in a growth chamber at $14^{\circ} \mathrm{C}$ with a 24-h photoperiod illumination. Twenty-one clones of $R$. padi and 21 clones of $S$. avenae were used. All the clones were collected in France during 1992 to 1994, except one clone of $R$. padi, $\mathrm{Rp}-\mathrm{CH}$, which was obtained in Harbin in northeast China in 1994 (Table 1). Among the clones of $S$. avenae, Sa-R5 was previously demonstrated by the entomological laboratory of National Institute for Agricultural Research (INRA) in Rennes to poorly transmit an isolate of BYD-PAV (C. A. Dedryver, unpublished). Following the collections, the aphids were confirmed to be BYDV-free by TAS-ELISA (2) and were used to start clonal population by transferring single apterous adults to barley seed- 
lings that were maintained in a growth chamber at $14^{\circ} \mathrm{C}$, with a 24-h photoperiod and a light intensity of 10,000 lux (12). For continuous maintenance of the clones, two nymphs of each clone were transferred to new barley seedlings every month, and the transfer was carried out in an isolated area to avoid contamination between clones. The seedlings on which the aphid clones were raised were frequently checked by TAS-ELISA to ensure that the aphids were virus-free.

Assessment of vector efficiency. Transmission tests were conducted at $14^{\circ} \mathrm{C}$ in a growth chamber with a 16-h photoperiod. Infected barley seedlings served as source plants 2 to 4 weeks after virus inoculation. The apterous adults of each clone were allowed to feed on three to four source plants for a 5-day acquisition access period (AAP). Twenty aphids of each clone and one leaf of each source plant were then collected and stored at $-20^{\circ} \mathrm{C}$, while 30 aphids of each clone were singly transferred to individually caged, healthy barley cv. Plaisant seedlings. After a 5-day inoculation access period (IAP), 20 of the transferred aphids of each clone were recovered and stored at $-20^{\circ} \mathrm{C}$. Following this preliminary transmission test, the three aphid clones from each species that showed the lowest transmission efficiency were chosen for additional replicate transmission tests. Five replications were carried out to test each of the six clones, with 30 apterous aphids in every repetition.

Variations of vector efficiency and virus regulation in aphids. To determine whether the variation in vector efficiency was associated with the ability of the various clones to retain virus, a serial transmission test of 11 days at 2-day intervals was performed with three $R$. padi clones-Rp$\mathrm{CH}, \mathrm{Rp}-\mathrm{R} 26, \mathrm{Rp}-\mathrm{Mir} 1-$ and three $S$. avenae clones, Sa-R5, Sa-V, and Sa-Chat1. After a 5-day AAP on source plants, 20 aphids of each clone were collected and frozen at $-20^{\circ} \mathrm{C}$, and 120 of the remaining aphids of each clone were allowed to infest the healthy barley seedlings with a single aphid per caged seedling. At each of the six transfers, 20 aphids of each clone were recovered and frozen at $-20^{\circ} \mathrm{C}$. All the inoculated barley seedlings were then treated with insecticide to kill the remaining aphids. The seedlings were grown in the growth chamber at least 2 weeks for virus

Table 1. Comparison of vector efficiency and virus titer in source plants and in aphids of 42 clones in transmitting a French BYD-PAV isolate to barley cv. Plaisant plants ${ }^{\mathrm{a}}$

\begin{tabular}{|c|c|c|c|c|c|c|c|}
\hline \multirow[b]{2}{*}{ Species } & \multicolumn{2}{|c|}{ Clone } & \multicolumn{3}{|c|}{ Virus titer } & \multirow[b]{2}{*}{ Vector efficiency } & \multirow[b]{2}{*}{ Source location } \\
\hline & No. & Name & Source plants & Aphids after AAP & Aphids after IAP & & \\
\hline \multirow[t]{22}{*}{ Rhopalosiphum padi } & 1 & $\mathrm{Rp}-\mathrm{A}$ & $0.684 \pm 0.102^{b}$ & $0.402 \pm 0.040$ & $0.243 \pm 0.011$ & 90.00 & Andard \\
\hline & 2 & $\mathrm{Rp}-\mathrm{C} 1$ & $0.723 \pm 0.074$ & $0.374 \pm 0.057$ & $0.189 \pm 0.032$ & 77.80 & Carbonne \\
\hline & 3 & $\mathrm{Rp}-\mathrm{C} 2$ & $0.738 \pm 0.010$ & $0.343 \pm 0.031$ & $0.207 \pm 0.049$ & 60.00 & Carbonne \\
\hline & 4 & $\mathrm{Rp}-\mathrm{Ca} 1$ & $0.643 \pm 0.044$ & $0.287 \pm 0.035$ & $0.153 \pm 0.011$ & 87.70 & Casterat \\
\hline & 5 & $\mathrm{Rp}-\mathrm{Ca} 2$ & $0.531 \pm 0.036$ & $0.392 \pm 0.075$ & $0.203 \pm 0.010$ & 87.10 & Casterat \\
\hline & 6 & $\mathrm{Rp}-\mathrm{CH}$ & $0.673 \pm 0.036$ & $0.342 \pm 0.047$ & $0.066 \pm 0.011$ & 26.70 & Harbin $^{c}$ \\
\hline & 7 & Rp-Chat & $0.710 \pm 0.067$ & $0.459 \pm 0.046$ & $0.242 \pm 0.030$ & 76.70 & Chateauroux \\
\hline & 8 & Rp-Mir1 & $0.254 \pm 0.058$ & $0.208 \pm 0.028$ & $0.048 \pm 0.010$ & 43.30 & Mirande \\
\hline & 9 & Rp-Mir2 & $0.762 \pm 0.026$ & $0.347 \pm 0.030$ & $0.132 \pm 0.021$ & 56.70 & Mirande \\
\hline & 10 & Rp-Mir3 & $0.700 \pm 0.045$ & $0.392 \pm 0.031$ & $0.146 \pm 0.038$ & 76.70 & Mirande \\
\hline & 11 & Rp-M & $0.662 \pm 0.110$ & $0.406 \pm 0.031$ & $0.237 \pm 0.046$ & 93.30 & Montmirail \\
\hline & 12 & $\mathrm{Rp}-\mathrm{N}$ & $0.423 \pm 0.075$ & $0.319 \pm 0.055$ & $0.182 \pm 0.013$ & 80.00 & Normandie \\
\hline & 13 & Rp-Or & $0.726 \pm 0.041$ & $0.372 \pm 0.065$ & $0.217 \pm 0.038$ & 80.00 & Orléans \\
\hline & 14 & Rp-R9 & $0.622 \pm 0.125$ & $0.416 \pm 0.057$ & $0.187 \pm 0.065$ & 63.30 & Rennes \\
\hline & 15 & $\mathrm{Rp}-\mathrm{R} 26$ & $0.632 \pm 0.00$ & $0.440 \pm 0.036$ & $0.178 \pm 0.046$ & 40.00 & Rennes \\
\hline & 16 & $\mathrm{Rp}-\mathrm{St}$ & $0.553 \pm 0.076$ & $0.374 \pm 0.081$ & $0.249 \pm 0.066$ & 93.30 & St. Jean liniere \\
\hline & 17 & $\mathrm{Rp}-\mathrm{S}$ & $0.694 \pm 0.010$ & $0.387 \pm 0.087$ & $0.218 \pm 0.056$ & 93.30 & Sermaise \\
\hline & 18 & $\mathrm{Rp}-\mathrm{Sp}$ & $0.472 \pm 0.067$ & $0.354 \pm 0.047$ & $0.152 \pm 0.036$ & 63.30 & St. pierre \\
\hline & 19 & $\mathrm{Rp}-\mathrm{Va}$ & $0.762 \pm 0.031$ & $0.369 \pm 0.085$ & $0.164 \pm 0.060$ & 73.30 & Valence \\
\hline & 20 & $\mathrm{Rp}-\mathrm{V} 1$ & $0.570 \pm 0.053$ & $0.400 \pm 0.036$ & $0.164 \pm 0.013$ & 60.00 & Versailles \\
\hline & 21 & $\mathrm{Rp}-\mathrm{V} 2$ & $0.439 \pm 0.047$ & $0.321 \pm 0.085$ & $0.152 \pm 0.010$ & 70.00 & Versailles \\
\hline & & $\mathrm{CK}$ & $0.063 \pm 0.021$ & $0.076 \pm 0.018$ & $0.064 \pm 0.017$ & 0.00 & \\
\hline \multirow[t]{22}{*}{ Sitobion avenae } & 1 & Sa-B & $0.474 \pm 0.056$ & $0.258 \pm 0.013$ & $0.164 \pm 0.009$ & 56.70 & Bois d'Arcy \\
\hline & 2 & $\mathrm{Sa}-\mathrm{C} 1$ & $0.642 \pm 0.076$ & $0.269 \pm 0.043$ & $0.144 \pm 0.021$ & 46.70 & Carbonne \\
\hline & 3 & $\mathrm{Sa}-\mathrm{C} 2$ & $0.832 \pm 0.043$ & $0.279 \pm 0.010$ & $0.057 \pm 0.026$ & 60.00 & Carbonne \\
\hline & 4 & Sa-Chat1 & $0.832 \pm 0.021$ & $0.368 \pm 0.087$ & $0.132 \pm 0.056$ & 10.00 & Chateauroux \\
\hline & 5 & Sa-Chat2 & $0.762 \pm 0.023$ & $0.384 \pm 0.051$ & $0.178 \pm 0.066$ & 56.70 & Chateauroux \\
\hline & 6 & Sa-Civ & $0.674 \pm 0.078$ & $0.388 \pm 0.056$ & $0.243 \pm 0.065$ & 43.30 & Civry \\
\hline & 7 & Sa-M1 & $0.856 \pm 0.010$ & $0.408 \pm 0.016$ & $0.177 \pm 0.046$ & 73.30 & Meulan \\
\hline & 8 & Sa-M2 & $0.673 \pm 0.085$ & $0.344 \pm 0.068$ & $0.184 \pm 0.046$ & 50.00 & Meulan \\
\hline & 9 & Sa-Mo1 & $0.382 \pm 0.033$ & $0.204 \pm 0.056$ & $0.078 \pm 0.035$ & 40.00 & Mouet \\
\hline & 10 & Sa-Mo2 & $0.732 \pm 0.046$ & $0.411 \pm 0.057$ & $0.245 \pm 0.042$ & 60.00 & Mouet \\
\hline & 11 & Sa-No.3 & $0.704 \pm 0.032$ & $0.422 \pm 0.043$ & $0.181 \pm 0.033$ & 63.30 & No.3 \\
\hline & 12 & $\mathrm{Sa}-\mathrm{P}$ & $0.564 \pm 0.073$ & $0.286 \pm 0.056$ & $0.143 \pm 0.072$ & 53.30 & Parcelle \\
\hline & 13 & Sa-R1 & $0.765 \pm 0.022$ & $0.483 \pm 0.014$ & $0.278 \pm 0.011$ & 76.70 & Rennes \\
\hline & 14 & Sa-R5 & $0.460 \pm 0.120$ & $0.304 \pm 0.085$ & $0.173 \pm 0.067$ & 0.00 & Rennes \\
\hline & 15 & Sa-R48 & $0.712 \pm 0.033$ & $0.312 \pm 0.054$ & $0.154 \pm 0.038$ & 41.90 & Rennes \\
\hline & 16 & Sa-R54-1 & $0.632 \pm 0.020$ & $0.321 \pm 0.065$ & $0.213 \pm 0.075$ & 70.00 & Rennes \\
\hline & 17 & Sa-R54-2 & $0.436 \pm 0.087$ & $0.324 \pm 0.040$ & $0.172 \pm 0.053$ & 46.70 & Rennes \\
\hline & 18 & Sa-Va1 & $0.721 \pm 0.086$ & $0.423 \pm 0.020$ & $0.208 \pm 0.016$ & 70.00 & Valence \\
\hline & 19 & $\mathrm{Sa}-\mathrm{Va} 2$ & $0.463 \pm 0.047$ & $0.358 \pm 0.056$ & $0.186 \pm 0.065$ & 60.00 & Valence \\
\hline & 20 & $\mathrm{Sa}-\mathrm{Va} 3$ & $0.732 \pm 0.012$ & $0.424 \pm 0.076$ & $0.258 \pm 0.034$ & 50.00 & Valence \\
\hline & 21 & $\mathrm{Sa}-\mathrm{V}$ & $0.463 \pm 0.056$ & $0.352 \pm 0.057$ & $0.077 \pm 0.033$ & 13.30 & Versailles \\
\hline & & CK & $0.054 \pm 0.00$ & $0.059 \pm 0.043$ & $0.068 \pm 0.010$ & 0.00 & \\
\hline
\end{tabular}

${ }^{a}$ Apterous adults of each aphid clone were allowed to infest source plants for a 5-day acquisition access period (AAP); then 30 aphids of each clone were singly transferred to individually caged healthy barley seedlings for a 5-day inoculation access period (IAP). Virus titer in source plants and in a batch of 10 aphids after AAP and IAP was measured by triple antibody sandwich-enzyme-linked immunosorbent assay (TAS-ELISA).

${ }^{\mathrm{b}}$ Virus titer $\left(A_{405}\right.$ OD values) determined by TAS-ELISA in source plants and in tested aphids after a 5-day AAP and IAP, respectively.

c The clone was collected from Harbin in the northeast of China. 
detection. All the transmission results were determined by TAS-ELISA. TAS-ELISA values with an absorbance at $A_{405} \mathrm{~nm}$ greater than 2 times the healthy controls were considered positive.

Estimation of virus titer in aphids and source plants by TAS-ELISA. Each sample of 20 viruliferous aphids collected after a 5-day AAP, IAP, and during the 11-day serial transfers was separately extracted in a sterile microtube with $200 \mu \mathrm{l}$ of PBST $\mathrm{pH} 7.4$, containing $1 \%$ (wt/vol) polyvinyl pyrrolidone, $0.1 \%$ bovine serum albumin, and $0.1 \%$ Triton X-100 (6). An equal number of nonviruliferous aphids extracted in the same buffer were used as a negative control. The leaves of source plants fed upon by the aphids of each clone were ground and diluted 1:10 (wt/vol) in PBST without Triton X-100. Extracts of virusfree barley plants were used as controls. TAS-ELISA was carried out in duplicate wells $(100 \mu \mathrm{l}$ per well) of two microplates to estimate virus titer in the source plants and in a batch of 20 aphids, respectively. Each group consisting of 20 aphids was divided into two samples of 10 aphids, which were tested in duplicate wells. TAS-
ELISA was done as described in Guo et al. (12).

Virus detection in aphids by IC-PCR. After an overnight incubation of antigen at $4^{\circ} \mathrm{C}$ in plates for TAS-ELISA, each of the samples was carefully recovered from wells with sterile pipettes for the IC-PCR experiment. A pair of BYD-PAV-specific oligonucleotide primers, B21 and B22, was used in the reverse transcription-PCR experiment. The primers were selected to amplify homologous regions of the capsid protein gene of BYD-PAV. The upstream primer, B21, (5'-TTC-GGC-CAG-TGGTTG-TGG-T-3') corresponds to bases 2931 to 2950 in the positive strand of the viral RNA, and the downstream primer, B22, (5'-TAC-TGC-ATC-GAC-TGT-CCA-C-3') corresponds to bases 3653 to 3672 on the complementary strand of BYD-PAV, resulting in a 722-bp amplified fragment. Ten microliters of each of the 20 aphid extracts removed from the TAS-ELISA plates was diluted to $50 \mu \mathrm{l}$ with extraction buffer and then transferred to a $0.6-\mathrm{ml}$ microcentrifuge tube that had been coated with $60 \mu \mathrm{l}$ of BYD-PAV polyclonal antibody $(2 \mu \mathrm{g} /$ $\mathrm{ml}$ ) for $3 \mathrm{~h}$ at $37^{\circ} \mathrm{C}$. After an overnight in-
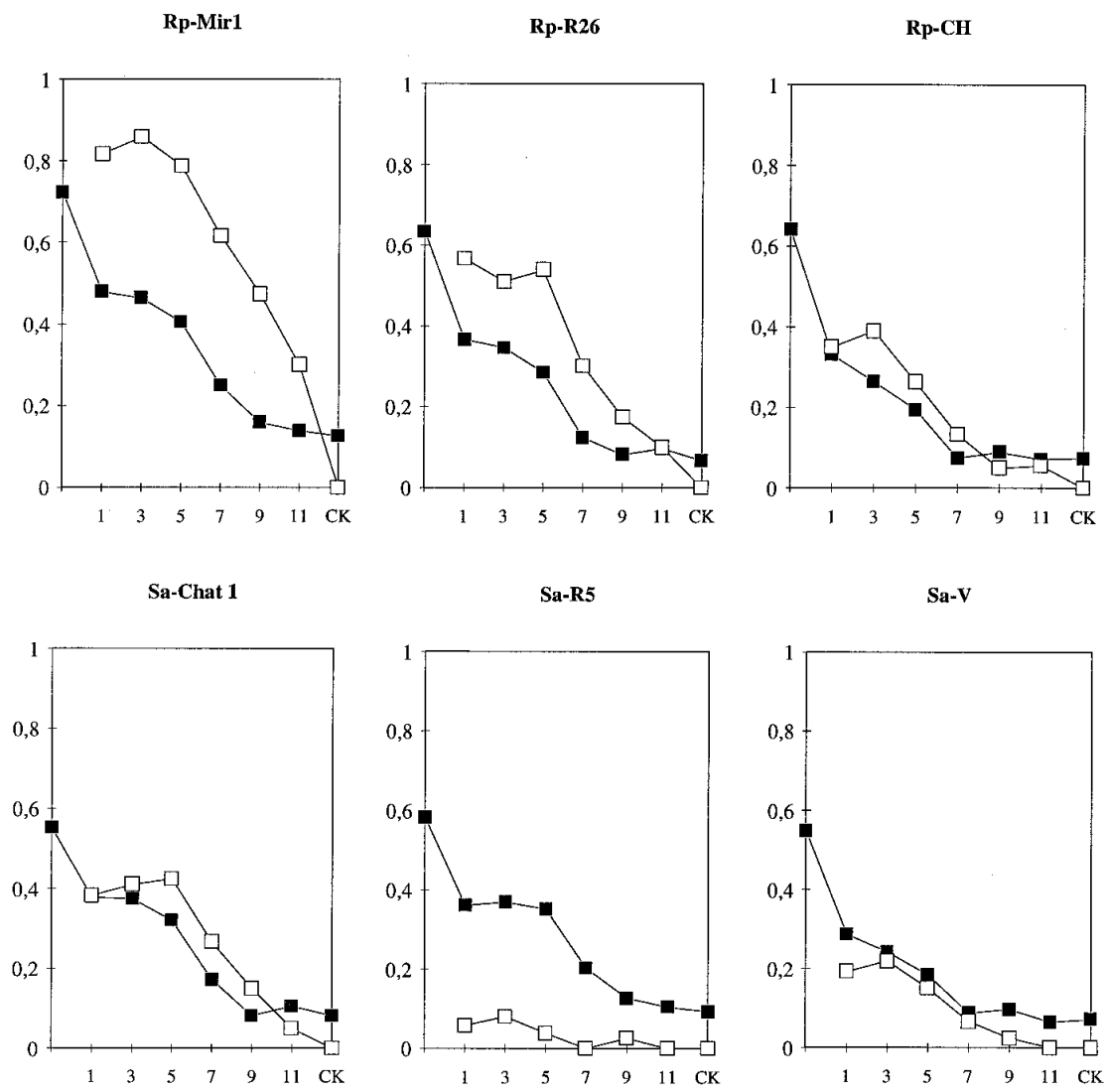

Days of serial transfer

Fig. 1. Transmission efficiency (-- $\square--)$ of PAV-RG isolate by aphids from six clones of Rhopalosiphum padi and Sitobion avenae and trend of virus titer (----, $A_{405}$ OD values) in a collection of 10 aphids of each clone after a 5-day acquisition access period on the source plants and a serial transfer of 11 days at 2-day intervals on the healthy barley plants. CK includes negative controls of nonviruliferous aphids for both transmission efficiency (-----) and virus titer (----) in the aphids, as determined by triple antibody sandwich-enzyme-linked immunosorbent assay.

cubation at $4^{\circ} \mathrm{C}$ for immunocapture of virions, the tubes were rinsed twice with PBST. Ten microliters of $1.5 \%$ Triton X100 was added to each tube and heated at $65^{\circ} \mathrm{C}$ for $10 \mathrm{~min}$ with vortexing to disrupt the antibody-bound virions and release viral RNA (32). To the $10 \mu \mathrm{l}$ of viral RNA released from the captured virions, $0.5 \mu \mathrm{M}$ antisense primer B22 was added and the mixture was heated for $5 \mathrm{~min}$ at $95^{\circ} \mathrm{C}$, and then chilled on ice for $2 \mathrm{~min}$ (17). A reverse-transcription mixture containing 50 $\mathrm{mM}$ Tris- $\mathrm{HCl}$ buffer (pH 8.3), $75 \mathrm{mM}$ $\mathrm{KCl}, 3 \mathrm{mM} \mathrm{MgCl} 2,10 \mathrm{mM}$ DTT, $1 \mathrm{mM}$ each dNTP, and 10 units of M-MLV reverse transcriptase (Promega, Madison, WI) was added in each tube, to yield a final volume of $20 \mu \mathrm{l}$. The reaction mixture for cDNA synthesis was incubated at $42^{\circ} \mathrm{C}$ for $1 \mathrm{~h}$. The cDNA was then denatured at $95^{\circ} \mathrm{C}$ for $5 \mathrm{~min}$ and amplified with 2.5 units of Taq DNA polymerase (Hi Taq, Bioprobe), $0.2 \mathrm{mM}$ each $\mathrm{dNTP}$, and 100 $\mathrm{mM}$ each oligonucleotide primer in a total of $50 \mu \mathrm{l}$ of PCR buffer $(50 \mathrm{mM} \mathrm{KCl}$, $10 \mathrm{mM}$ Tris- $\mathrm{HCl} \mathrm{pH} 9.0,0.1 \%$ Triton $\mathrm{X}$ 100 , and $2 \mathrm{mM} \mathrm{MgCl}_{2}$ ). Samples were overlaid with $50 \mu \mathrm{l}$ of Paraffin oil and placed in a DNA thermal cycler (model 480, Perkin Elmer). The amplification consisted of 32 cycles with two primary cycles of denaturation at $94^{\circ} \mathrm{C}$ for $10 \mathrm{~s}$, annealing at $55^{\circ} \mathrm{C}$ for $40 \mathrm{~s}$, and extension at $72^{\circ} \mathrm{C}$ for $1 \mathrm{~min}$, followed by 30 cycles of $10 \mathrm{~s}$ at $94^{\circ} \mathrm{C}, 40 \mathrm{~s}$ at $65^{\circ} \mathrm{C}$ and $1 \mathrm{~min}$ at $72^{\circ} \mathrm{C}$. The final cycle concluded with 10 $\min$ at $72^{\circ} \mathrm{C}$. Reverse transcription-PCR amplification products were analyzed by electrophoresis of $10 \mu \mathrm{l}$ of PCR reaction aliquots on $1.5 \%$ agarose gels stained with ethidium bromide.

\section{RESULTS}

Transmission efficiency of various aphid clones. The results of the preliminary transmission test (Table 1) showed that all the clones of $R$. padi could transmit PAV-RG, but with different transmission efficiencies. The highest transmission efficiency was two times greater than the lowest one among $R$. padi clones (Table 1). Twenty aphid clones of $S$. avenae transmitted this virus with a transmission efficiency more variable than that of $R$. padi clones. None of the 30 aphids of the $S$. avenae clone Sa-R5 transmitted the virus in the preliminary transmission test (Table 1).

Three $R$. padi and $S$. avenae clones that transmitted the virus with less than 50 and $30 \%$ efficiency in the preliminary test, respectively, were chosen for replicate transmission tests. The results from the five tests demonstrated that the $\mathrm{Rp}-\mathrm{CH}$ clone was the least efficient $R$. padi clone. Only $38.7 \% \pm 6.9 \%$ of 150 aphids transmitted the PAV-RG isolate. The Rp-R26 and Rp-Mir1 clones transmitted the virus to $54.7 \% \pm 6.9 \%$ and $84 \% \pm 10.7 \%$ of the tested plants, respectively. The Sa-R5, Sa- 
$\mathrm{V}$, and Sa-Chat 1 clones of S. avenae had transmission efficiencies of $8.7 \% \pm 3.8 \%$, $18.7 \% \pm 6.9 \%$, and $34.8 \% \pm 9.1 \%$, respectively.

Vector efficiency and virus titer in aphids. Most infected barley plants in the initial test contained a relatively high virus titer (more than 0.5 OD value) by TASELISA and served as good virus sources. However, the source plants for the RpMir1 clone contained the lowest virus titer (0.254 OD value). The aphids feeding on these plants acquired too little virus to be detected by TAS-ELISA in a batch of 10 aphids after a 5-day IAP on healthy barley plants (Table 1). Vector efficiency of this clone correlated with the low virus titer in the aphids. Only $43 \%$ of tested plants became infected in the preliminary test, compared with the $84 \%$ transmission efficiency in the replicated test. In contrast, the source plants for the Sa-Chat 1 clone contained a relatively high virus titer. However, this aphid clone transmitted poorly, yielding an efficiency of $10 \%$. TAS-ELISA failed to detect the virus in the aphids of this clone after a 5-day IAP (Table 1).

After a 5-day AAP on the source plants, the virus titer detected by TAS-ELISA was different in the aphid clones. A regression analysis was performed to calculate the correlation coefficients among virus titer in source plants, virus titer acquired and retained by aphids, and transmission efficiency. The results indicated that PAV-RG titer in the source plants was significantly correlated with that acquired by $R$. padi $\left(r_{0.05}=0.5108>0.4227\right)$ and $S$. aveane $\left(r_{0.01}=0.5723>0.5368\right)$. But the virus titer in the aphids of both species after the 5day AAP had no significant correlation with their transmission efficiency ( $R$. padi, $r_{0.05}=0.2332<0.4227 ; S$. avenae, $r_{0.05}=$ $0.0914<0.4227)$. The virus titer in the aphids after a 5-day IAP was significantly correlated with transmission efficiency of the tested clones of both species ( $R$. padi, $r_{0.001}=0.7493>0.6524 ; S$. avenae, $r_{0.05}=$ $0.4230>0.4227$ ). In most cases, higher transmission efficiency was associated with greater PAV-RG titer retained in the aphids after inoculation feeding. More reduced PAV-RG titer in the aphids was often associated with poorer vector efficiency. For example, low transmission efficiency was observed with a $R$. padi clone, $\mathrm{Rp}-\mathrm{CH}$, and a $S$. avenae clone, $\mathrm{Sa}-\mathrm{V}$, and TASELISA failed to detect the virus in the batch of 10 aphids of both clones after a 5day IAP (Table 1). However, in a few cases, a relatively high or low PAV-RG titer retained in the aphids could not be correlated with transmission efficiency. For example, none of 30 aphids of $S$. avenae clone Sa-R5 transmitted in the preliminary transmission test, but the virus could be still detected by TAS-ELISA in the aphids after the 5-day IAP (Table 1).

Detection of PAV-RG in the extract of a single aphid of each clone by IC-PCR con- firmed that virus could be acquired as well as retained by the aphids of all the clones of both species after a 5-day AAP and IAP on barley plants (data not shown).

Variations in vector efficiency and virus regulation by aphids. The serial transmission test revealed that PAV-RG could be successively transmitted by three aphid clones, Rp-Mir1, Rp-R26, and Rp$\mathrm{CH}$, of $R$. padi and one clone of $S$. avenae, Sa-Chat1, until the last transfer at 11 days. But, the virus was transmitted by the Sa$\mathrm{R} 5$ and $\mathrm{Sa}-\mathrm{V}$ clones of $\mathrm{S}$. avenae only up to 9 days (Fig. 1). However, after five daily transfers, vector efficiency declined prominently in all six clones of the two species. Variation in vector efficiency at transmitting PAV-RG was consistently observed in the serial transmission test as compared with the preceding observation in the replicated transmission tests (Fig. 1).

In the serial transmission test, TASELISA results indicated that PAV-RG titer acquired by the aphids was similar among the six clones of the two species. Following the daily serial transfer for 11 days on healthy barley plants, PAV-RG titer in the aphids decreased in triphase. In the triphasic trend, the initial decrease occurred rapidly after the first transfer and then the virus titer decreased slowly, but a second rapid reduction occurred after the 7th-day transfer. However, while PAV-RG titer declined more rapidly in the second phase, the triphasic trend observed in PAV-RG titer was not quite as obvious in the $\mathrm{Sa}-\mathrm{V}$ and $\mathrm{Rp}-\mathrm{CH}$ clones. After seven daily transfers, the virus could not be detected by TAS-ELISA in the batch of 10 aphids. However, PAV-RG could be detected by TAS-ELISA in the batch of 10 aphids in the remaining clones until after the 9th-day transfer (Fig. 1).

During the serial transmission, vector efficiency in each transfer was significantly correlated with the virus titer retained in the aphids among five of these six clones $\left(r_{0.05}=0.7950\right.$ to $\left.0.8891>0.7545\right)$, but vector efficiency of the Sa-R5 clone was not significantly associated with the virus titer in the aphids $\left(r_{0.05}=0.5956<0.7545\right)$.

In contrast to TAS-ELISA results, the virus amplification by IC-PCR confirmed that the Rp-Mir1, Rp-R26, Rp-CH, Sa-R5, and Sa-Chat 1 clones could retain PAV-RG until the last transfer at 11 days, but $\mathrm{Sa}-\mathrm{V}$ clone only retained this virus for up to 9 days during the serial transmission test (Fig. 2).

\section{DISCUSSION}

Earlier studies have shown that aphid clones within a species vary in their ability to transmit BYDV $(10,12,20,21)$. Our study shows that aphid clones of $R$. padi and $S$. avenae, the two most efficient vector species of BYD-PAV, are no exception. At least two or three individuals among 21

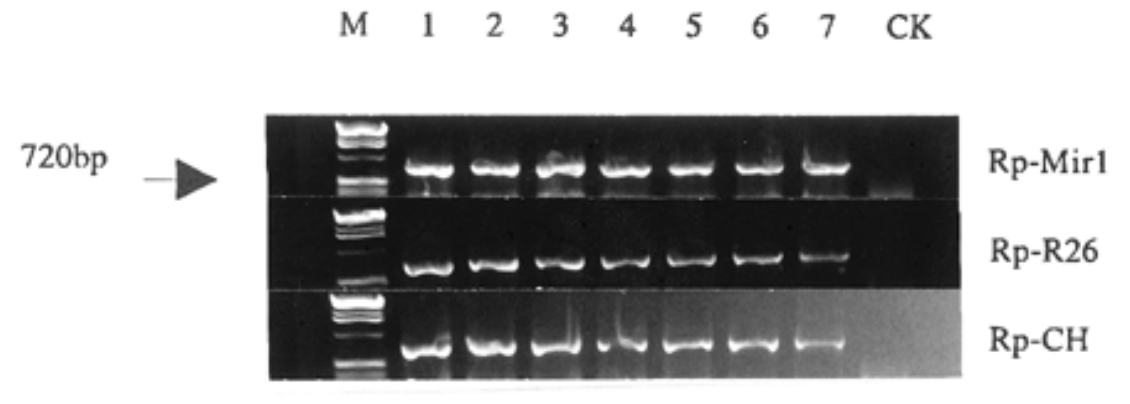

A

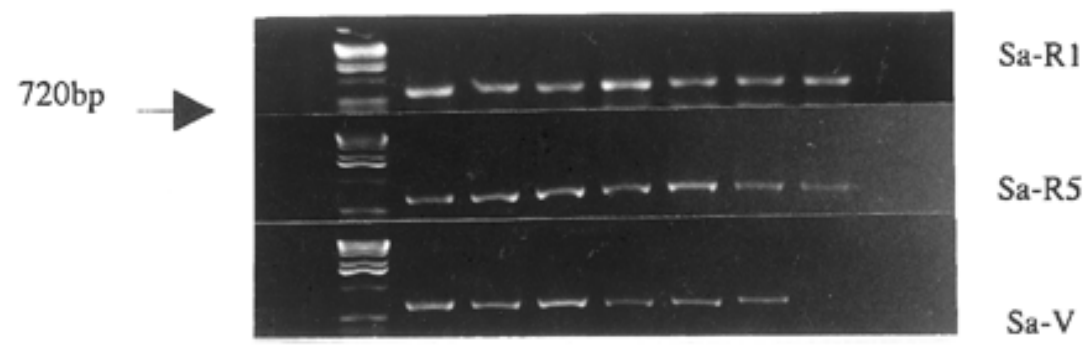

B

Fig. 2. Agarose gel electrophoretic analyses of the products amplified by immunocapturepolymerase chain reaction from the extract of a single aphid of Rp-Mir1, Rp-R26, and Rp-CH clones of Rhopalosiphum padi (A) and Sa-Chat1, Sa-R5, and Sa-V clones of Sitobion avenae (B) that had an acquisition access period (AAP) of 5 days on source plants and a serial transfer of 11 days at 2 day intervals on the healthy barley seedlings. Lane M: 1-kb DNA size marker (arrow indicates 720 bp); lane 1: viruliferous aphids after a 5-day AAP; lanes 2 to 7: viruliferous aphids after 1, 3, 5, 7, 9, and 11 days, respectively, of transfers on healthy barley plants; lane CK: nonviruliferous aphids as negative controls. 
aphid clones of $R$. padi and $S$. avenae vary in their efficiency to transmit a French PAV-type isolate (PAV-RG). Vector efficiency among $S$. avenae clones was more variable than among $R$. padi clones. The Sa-R5, Sa-V, and Sa-Chat1 clones were about eight-, four, and twofold less efficient, respectively, than the most efficient $S$. avenae clone. The Rp-CH and Rp-R26 clones of $R$. padi were only about twofold less efficient than the most efficient clones within the species. As TAS-ELISA can be used to quantitatively assess virus titer retained in a group of viruliferous aphids, IC-PCR makes it possible to determine the duration of virus retention in the aphids. Application of both IC-PCR and TASELISA techniques in studying relatedness between the clonal variations and BYDV regulation in aphids showed that the variation in vector efficiency among the clones found in this study was not attributed to poor ability to acquire the virus.

Among the variants in the two species, low vector efficiency of the Sa-V and Rp$\mathrm{CH}$ clones was partly associated with a more rapid decrease in virus titer in the aphids as determined by TAS-ELISA during the 11 days of serial transfer. However, the lowest efficiency from Sa-R5, the least efficient clone, had no significant correlation to the decrease of virus titer in the aphids. Sa-R5 poorly transmitted the virus only for 9 daily transfers, even though the virus could be retained in the aphids until the last transfer at 11 days, as determined by IC-PCR. Therefore, this suggests that clonal variations in vector efficiency could possibly be associated with a transmission barrier in the aphids that prevents the virions passing from accessory salivary glands (ASG) (9), as well as a poor retention of virus titer in the hemolymph of aphids in which the virions might be proteolytically degraded (28). The variation in vector efficiency associated with the transmission barrier in the aphids could be caused by an alteration of the membrane structure of the aphid's ASG such that only a few recognition sites could efficiently allow the virions to pass through the ASG membrane. However, the variation partly related to the poor retention of virus titer by the aphids could also be due to a more rapid elimination of virions in the hemocoel of aphid.

During the serial transfer, PAV-RG titer decreased triphasically in the aphids, regardless of the transmission efficiency. We propose that the initial decrease that showed rapidly after the first transfer probably occurs at the gut of aphids, because this initial decrease had no any effect on vector efficiency of the tested aphid clones. Subsequent decreases of virus titer in aphids, particularly the second rapid reduction, were always associated with the decline of vector efficiency. Therefore, we suggest that these decreases probably occur in the hemocoel, where they may be linked with elimination of virions in aphids.
These are similar to that of PLRV titer in the aphid $M$. persicae (25). But the trend of PLRV titer in $M$. persicae had no second rapid reduction after the initial decrease. Throughout the second phase, PLRV titer decreased slowly in $M$. persicae (25). Following the 11 days of serial transfer, the continuous decrease in PAV-RG titer in the aphids suggests that BYD-PAV does not replicate in the aphids of $R$. padi and $S$. avenae and the duration of virus retention by some aphid clones may also be limited, as the virions are eliminated from aphids. Furthermore, transmission efficiency of vector aphids was significantly correlated with virus titer retained in the aphids. The capacity to retain virus should be considered in the assessment of aphid vector efficiency, because it plays a very important role in virus epidemiology.

In our previous tests, we found that BYDV titer decreased in the aphids of both vector and nonvector species following serial transfer feedings on healthy barley plants. In the nonvector aphid species, the virus titer decreased more rapidly than in the vector species. Furthermore, environmental factors also have an important influence on the retention period of BYDV in aphids. When a serial transfer experiment was done in a greenhouse at 20 to $35^{\circ} \mathrm{C}$ in summer, both transmission and retention period of BYDV became shorter than 10 days in the aphids of tested species. Therefore, the retention period of BYDV in aphids can be changed by the influence of environmental factors. But, why a relatively rapid decrease of virus titer in the aphids occurred after 7-day inoculation periods in our controlled conditions and why the decrease in the aphids of nonvector species was more rapid than that of vector species are unexplained.

IC-PCR has been previously demonstrated to provide detection of BYDV in aphids more sensitive than that provided by conventional PCR. However, percentage of viruliferous aphids as determined by IC-PCR cannot be directly used to estimate transmission percentage and thus predict disease. Since there are variants in vector efficiency among aphid clones within species caused by the transmission barrier of virions as well as the relatively rapid degradation of virions in the hemocoel of aphids, not all viruliferous vector aphids can efficiently transmit BYDV.

\section{ACKNOWLEDGMENTS}

We deeply thank C. A. Dedryver, Unité de Zoologie, INRA, Domaine de la Motte, for the gift of all the aphid clones from Rennes, and B. Chalhoub, Unité de Pathologie Végétale, for providing primers. We are also indebted to P. Touton, a technician of Unité de Zoologie, INRA, in Versailles for his helpful assistance. Thanks are also due to R. Lepetit and S. Paillard, Service Régional de la Protection des Végétaux in the Regions of BaseNormandie and Angers, for their cordial collaboration in sampling of aphid clones.
LITERATURE CITED

1. Ahoonmanesh, A., Hajimorad, M. R., Ingham, B. J., and Francki, R. I. B. 1990. Indirect double antibody sandwich ELISA for detecting alfalfa mosaic virus in aphids after short probes on infected plants. J. Virol. Methods 30:271-282.

2. Beuve, M., and Lapierre, H. 1992. Resistance to RPV barley yellow dwarf virus in the genus Bromus. Can. J. Bot. 70:32-37.

3. Chalhoub, A. B., Sarrafi, A., Beuve, M., and Lapierre, H. 1994. Differential interaction between PAV-like isolates of barley yellow dwarf virus and barley (Hordeum vulgare L.). J. Phytopathol. 142:189-198.

4. Conti, M. C., D'Arcy, J., Jedlinski, H., and Burnett, P. A. 1990. The "Yellow Plague" of cereals, barley yellow dwarf virus. Pages 1-6 in: World Perspectives on Barley Yellow Dwarf. P. A. Burnett, ed. CIMMYT, Mexico City D. F.

5. Creamer, R., and Falk, W. B. 1990. Direct detection of transcapsidated barley yellow dwarf luteoviruses in doubly infected plants. J. Gen. Virol. 71:211-217.

6. Ding, X. S., Cockbain, A. J., and Govier, D. A. 1992. Improvements in the detection of pea seed-borne mosaic virus by ELISA. Ann. Appl. Biol. 121:75-83.

7. Esmenjaud, D., Abad, P., Pinck, L., and Walter, B. 1994. Detection of a region of the coat protein gene of grapevine fanleaf virus by RTPCR in the nematode vector Xiphinema index. Plant Dis. 78:1087-1090.

8. Gildow, F. E. 1993. Evidence for receptor-mediated endocytosis regulating luteovirus acquisition by aphids. Phytopathology 83:270277.

9. Gildow, F. E., and Gray, S. M. 1993. The aphid salivary gland basal lamina as a selective barrier associated with vector-specific transmission of barley yellow dwarf luteoviruses. Phytopathology 83:1293-1302.

10. Gildow, F. E., and Rochow, W. F. 1983. Barley yellow dwarf in California: Vector competence and luteovirus identification. Plant Dis. 67:140-143.

11. Gill, C. C. 1970. Aphid nymphs transmit an isolate of barley yellow dwarf virus more efficiently than do adults. Phytopathology 60: 1747-1752.

12. Guo, J. Q., Moreau, J. P., and Lapierre, H. 1996. Variability among aphid clones of Rhopalosiphum padi L. and Sitobion avenae Fabr. (Homoptera : Aphididae) in transmission of three PAV isolates of barley yellow dwarf viruses. Can. Entomol. 128:209-217.

13. Jansen, R. W., Siegl, G., and Lemon, S. M. 1990. Molecular epidemiology of human hepatitis A virus defined by an antigen-capture polymerase chain reaction method. Proc. Natl. Acad. Sci. USA 87:2867-2871.

14. Jolly, C. A., and Mayo, M. A. 1994. Changes in the amino acid sequence of the coat protein readthrough domain of potato leafroll luteovirus affect the formation of an epitope and aphid transmission. Virology 201:182-185.

15. Lopez-Moya, J. J., Cubero, J., Lopez-Abella, D., and Diaz-Ruiz, R. J. 1992. Detection of cauliflower mosaic virus (CaMV) in single aphids by the polymerase chain reaction (PCR). J. Virol. Methods 37:129-138.

16. Peiffer, M. L., Gildow, F. E., and Gray, S. M 1993. Effect of the salivary gland basal lamina on transmission efficiency of barley yellow dwarf virus (BYDV) by aphids. Phytopathology 83:1403

17. Robertson, N. L., French, R., and Gray, S. M 1991. Use of group-specific primer and the polymerase chain reaction for the detection and identification of luteoviruses. J. Gen. Virol. 72:1473-1477.

18. Rochow, W. F. 1969. Biological properties of 
four isolates of barley yellow dwarf virus. Phytopathology 59:1580-1589.

19. Rochow, W. F. 1970. Barley yellow dwarf virus. No. 32 in: Descriptions of Plant Viruses. Commonw. Mycol. Inst./Assoc. Appl. Biol., Kew, England.

20. Rochow, W. F., and Eastop, F. V. 1966. Variation within Rhopalosiphum padi and transmission of barley yellow dwarf virus by clones of four aphid species. Virology 30: 286-296.

21. Saksena, K. N., Singh, S. R., and Sill, W. H. 1964. Transmission of barley yellow dwarf virus by four biotypes of the corn leaf aphid, Rhopalosiphum maidis. J. Econ. Entomol. 57: 569-571.

22. Smith, H. G., Stevens, M., and Hallsworth, P. B. 1991. The use of monoclonal antibodies to detect beet mild yellowing virus and beet western yellows virus in aphids. Ann. Appl. Biol. 119:295-302.

23. Takahashi, Y., Tiongco, R. E., Cabauatan, P. Q., Koganezawa, H., Hibino, H., and Omura, T. 1993. Detection of rice tungro bacilliform virus by polymerase chain reaction for assessing mild infection of plants and viruliferous vector leafhoppers. Phytopathology 83: 655-659.

24. Takeshi, S., Smith, C. L., and Cantor, C. R. 1992. Immuno-PCR: Very sensitive antigen detection by means of specific antibody-DNA conjugates. Science 258:120-122.

25. Tamada, T., and Harrison, B. D. 1981. Quantitative studies on the uptake and retention of potato leafroll virus by aphids in laboratory and field conditions. Ann. Appl. Biol. 98: 261-276.

26. Torrance, L. 1987. Use of enzyme amplification in an ELISA to increase sensitivity of detection of barley yellow dwarf virus in oats and in individual vector aphids. J. Virol. Methods 15:131-138.

27. van den Heuvel, J. F. J. M., and Peters, D. 1989. Improved detection of potato leafroll virus in plant material and in aphids. Phytopathology 79:963-967.

28. van den Heuvel, J. F. J. M., Verbeek, M., and van der Wilk, F. 1994. Endosymbiotic bacte- ria associated with circulative transmission of potato leafroll virus by Myzus persicae. J. Gen. Virol. 75:2559-2565.

29. Vega, F. E., Davis, E. R., Barbosa, P., Dally, E. L., Purcell, A. H., and Lee, I.-M. 1993 Detection of a plant pathogen in a nonvector insect species by the polymerase chain reaction. Phytopathology 83:621-624.

30. Wang, J. Y., Chay, C., Gildow, F. E., and Gray, S. M. 1995. Readthrough protein associated with virions of barley yellow dwarf luteovirus and its potential role in regulating the efficiency of aphid transmission. Virology 206:954-962.

31. Webby, G. N., Lister, R. M., and Burnett, P. A 1993. The occurrence of barley yellow dwarf viruses in CIMMYT bread wheat nurseries and associated cereal crop during 1988-1990. Ann. Appl. Biol. 123:63-74

32. Wetzel, T., Candresse, T., Macquaire, G Ravelonandro, M., and Dunez, J. 1992. highly sensitive immunocapture polymerase chain reaction method for pox potyvirus detection. J. Virol. Methods 39:27-37. 